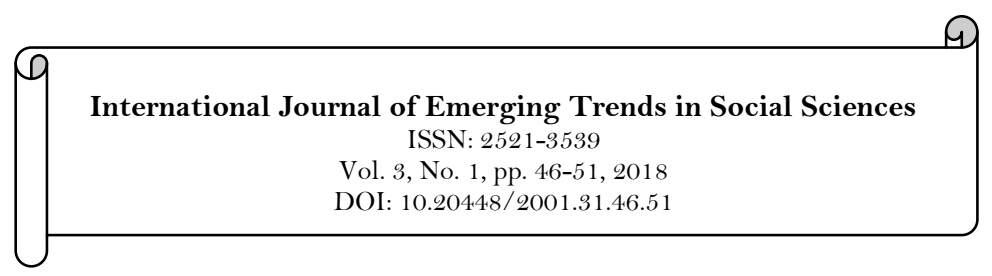

\title{
Home Background, Peer Group Pressure and Truancy among Secondary School Adolescent Students in Edo State, Nigeria
}

\author{
Jude J Obiunu's \\ Ozuri Rachael ${ }^{2}$ \\ 1,2Department of Guidance and Cpunselling Faculty of Education Delta State University, Abraka, Nigeria. \\ ${ }^{\prime}$ Email: Obiumu@yahoo.com
}

\begin{tabular}{|c|c|}
\hline Abstract & \\
\hline $\begin{array}{l}\text { This study examined the influence of home background, peer group } \\
\text { pressure and truancy among secondary school adolescent students of } \\
\text { Delta State. Three research questions and three hypotheses were } \\
\text { formulated to serve as a guide to the study. Correlational survey } \\
\text { research design was used for the study. The population of the study } \\
\text { consists of all students in all public secondary schools in the area of } \\
\text { the study. A sample of } 266 \text { students were used for the study using } \\
\text { the simple random sampling technique. A } 4 \text { point likert scale } \\
\text { questionnaire designed by the researcher was used for data } \\
\text { collection. The questionnaire was validated by professionals in the } \\
\text { area of research. Cronbach Alpha reliability was used to establish the } \\
\text { reliability of the instrument with an r-value of o.78. The statistical } \\
\text { tools for answering the research questions and for testing the } \\
\text { hypotheses were the Pearson r, coefficient of determination and the } \\
\text { Analysis of Variance (ANOVA). The findings revealed that there is a } \\
\text { significant relationship between home background and truancy } \\
\text { among secondary school students. Also, there is a significant } \\
\text { relationship between peer pressure and truancy among secondary } \\
\text { school students. The study also revealed that there is no significant } \\
\text { relationship between gender and truancy among secondary school } \\
\text { students. Based on the findings, it was recommended among others } \\
\text { that parents should learn to be close to their wards and as well take } \\
\text { note of the friends that they associate with as this will help to reduce } \\
\text { the level of peer influence on the development of truant behaviours } \\
\text { among students, Teachers and parents should help in proper } \\
\text { monitoring of student activities so as to help students to maximise } \\
\text { their potentials to the fullest and to be well adjusted in all } \\
\text { ramification of lives. Finally every parents and elder siblings should } \\
\text { see themselves as role models that engender good behaviours to } \\
\text { their children as the kind and form of mentoring given by parents } \\
\text { contributes in the sharpening of adolescent attitudes and behaviours. }\end{array}$ & $\begin{array}{l}\text { Keywords: } \\
\text { Truancy } \\
\text { Home background } \\
\text { Peer group pressure } \\
\text { Gender. } \\
\text { Licensed: } \\
\text { This work is licensed under a } \\
\text { Creative Commons Attribution } \\
\text { 4.0 License. } \\
\text { Publisher: } \\
\text { Scientific Publishing Institute }\end{array}$ \\
\hline
\end{tabular}

\section{Introduction}

The school is a social unit established by members of the society or the Government as a formal agency of education in which the young (students) attend to learn about themselves, other people, as well as the language, custom, attitude and the ways of doing things. Staying in school is the first step to a good education and in order to achieve academic excellence, the students are mandated by the school laws to attend school daily but due to some factors, most students absent themselves from formal school activities hence engaging in truancy. Stoll (2002) defines truancy as "absence from school for no legitimate reason". He went further to state that many students do skip either single class or even a full day school at least once during their academic career. This is because they may want to attend a special event with their peer groups such as football team, roaming about in street during school hours (Obe, 1998). This incidence (truancy) is quite typical and likely to create problems. 
Historically, the origin of truancy can be traced to the Massachusetts compulsory Education Act of 1647 and it subsequent school attendance act of 1852, which forced parents to send their children for at least 12 weeks in term (Michael, 2005). According to this Act, every school is by law required to notify any students who acquires five unexcused absent within a school year. However, it is through this unexcused absent from school without legitimate or legal knowledge of parents, guardian or the school that truancy among students came into being. Truancy among secondary school adolescent student is a situation in which students develop and show adverse attitude and behaviour of learning. They absent themselves from classes using unnecessary excuses such as in genuine sickness, fake suspension by the class teacher or school authority and involvement in sport activities.

The causes of truancy among secondary school adolescents have been attributed to lack of writing materials such as pen, pencil, exercise book, recommended textbooks, school uniform and middle meal (Obe, 1998). Poor home upbringing, school circumstances, psychological and personality factors, socio-economic status of the students, societal demands, influence of peer group and government influence (Osarenren, 1999). The government is also another major cause of truancy. This is attributed to the fact that government do not pay teachers regularly and most of their allowances such as leave allowance, sport and science allowance are being withheld. Most teachers find it difficult to be committed and dedicated to their primary duties of teaching. When this occurs and the students do not find their teacher in the class, the next plan of action is to engage in truant behaviour (Obe, 1998). It is common these days to see students roaming about in streets during school hours.

Home upbringing could influence students into truancy. Tracing the causes of truancy among secondary school adolescent students, Reid (2000) opined that truancy came from unsatisfactory situation, families on relief, broken home. Odueze (2001) assert that for education to be real and effective there should be sound cooperation between the home and the school. Bucci (2002) noted that truant students tend to leave school early as a result of factors associated with the home background of the students such as unemployment, povertyhomelessness, ill health's, drugs and alcohol abuse and family breakdown. According to Capps (2003) adolescent who involves in truancy tends to perceive the world around them as unstable, and confusing with many coming from dysfunction, unstable and insecure homes. Some parents due to the nature of their jobs, nonchalant attitudes to their ward and as such, they grow up to be corrupt and aggressive hence getting nothing and giving out nothing. Most parents do give too much money to their wards thus contributing to their truant behaviours. Gonzales, Richards, and Seeley (2002) states that involvement of parents on the education of their children have a significant impacts on students attendance and their general academic performance.

Peer group is another factor that could influence truancy. Ezewu (1983) peer groups are person of same age group, friends or equals with whom the child shares certain social characteristics. This social world to which they belongs could be one in which they share same language, values, norms and mode of interaction which may not be understood by the adults. However, it is through the peer pressure that students are most likely to be introduced and involved in truant behaviours such as drinking, smoking, indecent act and drop out of school

Factor like gender could also influence truancy among students. Azizi (2009) opined that gender is a sex race among student that get involve in truants behaviour. According to Azizi (2009) female students are more likely to be involved in truant behaviours due to their group population and career choice compared to male students. Opined that a boy or a girl can easily mess up a dozen of others of his friends in the school when a child who is very good (boy or girl) enters secondary school at formative age between ten and fourteen years, when such a child must have been in the school for two to three terms. You start wondering whether it is still your ward, because he will turn out to be a completely changed child, whereby he will be involve in truants behaviour. Gender is a sex race among students that are involved in truant behaviour. Base on this perspective, female students are more likely to be involved in truant behaviours due to their group population and career choice taken compared to male students (Azizi, 2009). Furthermore, Azizi posited that female students at adolescent age between (12-17) practice more of truant acts than the male students because they believe at this stage they are complete adult or becoming adult responsible for personal decision and tend to behave more disobediently as they are cautioned by their mental ability

\subsection{Statement of the Problem}

The objectives of secondary school education in Nigeria is to provide students with academic and vocational skills as well as moral ethics, but it is quite unfortunate that these objectives have not been fully achieved due to the high level of involvement in truant behaviours, Osarenren (1999). From this discussion it is observed that failure of many homes has yielded unwanted behaviours such as truancy in most students in secondary schools.

This is because broken home, polygamy and bad relationship within homes has made many parents not to have enough care for their children. When this care is not there, children tends to make use of their opportunity to display delinquent act even to the extents of insulting teachers, elders and staying away from school (truancy). The influence of peer group is very hard to curb simply because it is the second agent of 
socialization and this influences students to engage in truant act (Obe, 1998). Effects of truancy on the academic performance leads to poor academic student performance and examination malpractice which results to student's rustication and expulsion (Azizi, 2009). Due to this, this study investigated the relationship between home background, peer group pressure and truancy among secondary school adolescent students in Delta State.

\subsection{Research Questions}

To guide this study, the following research questions were raised:

- Is there any relationship between home background and truancy among secondary school adolescent students in Delta state?

- Is there any relationship between peer group pressure and truancy among adolescent students in Delta state?

- Is there any relationship between gender of students and truancy among adolescent students in Delta state?

\subsection{Hypotheses}

The following hypotheses were formulated and were tested at 0.05 level of significance:

Ho: 1 There is no significant relationship between home background and truancy among secondary school adolescent students in Delta State.

Ho: 2 There is no significant relationship between peer group pressure and truancy among secondary school adolescent studentsin Delta State.

Ho: 3 There is no significant relationship between gender of students and truancy among secondary school adolescent studentsin Delta State.

\subsection{Purpose of the Study}

The main purpose of this study examined the relationship between home background, peer group pressures and truancy among secondary school adolescents in Delta State. Specifically this study seeks to:

- Examine the relationship between home background and truancy among secondary school adolescents.

- Investigate the relationship between peer group pressure and truancy among secondary school adolescents.

Determine the relationship between gender and truancy among secondary school adolescents.

\section{Methodology}

The research design for this study is the correlational survey design which looked at the relationship between the variables of the study. The population for this study consists of all the senior secondary School 2 students enrolled during the 2016/2017 academic session in all the public senior secondary schools in Delta State. The simple random sampling technique was employed in this study. This was done by first of all carefully writing the names of the schools on a sheet of paper folded and put in a blind bag after which, the researcher picked. The first 5 schools picked constituted the sampled schools used for the study. The sample of this study consists of 266 students that were randomly selected from 5 schools. 53 students were randomly selected from each schools using simple random sampling techniques by balloting with replacement.

The instrument employed for this study is a self-constructed questionnaire titled Home background, peer group pressure and truancy among Students (HBPGPTAS). The Questionnaire is structured and divided into two sections. Section A and B. Section A contains general information of bio-data of the respondents. While section B comprised of 30 items that were used to elicit information on students' involvement in truancy on a 4 point likert scale from Strongly Agree 4points, Agree 3 points, Disagree 2 points and Strongly Disagree 1 point. The questionnaire was validated by professionals in the area of research. Cronbach Alpha reliability was used to establish the reliability of the instrument with an r-value of 0.78. The questionnaire was administered to the respondents personally by the researcher and all instruments where collected on the spot to aid high rate of retrieval. Data analysis was done using the statistical package of the social sciences version 17 (SPSS 17). In analysing the data, the person $r$, coefficient of determination was used to answer the research questions while inferential statistics such as Analysis of Variance (ANOVA) was used to test the hypotheses at 0.05 levels of significant

\section{Results}

Research Question One: is there any relationship between home background and truancy among secondary school adolescent students in Delta State? 
Table-1. Correlation between Home background and Truancy amongst secondary school Adolescen $\mathrm{t}$ students.

\begin{tabular}{l|l|l|l|l|l|l}
\hline Variable & $\mathbf{N}$ & $\mathbf{R}$ & $\mathbf{R}^{2}$ & $\mathbf{A d j .} \mathbf{R}^{2}$ & $\mathbf{S E E}$ & $\mathbf{R}^{2 \%}$ \\
\hline Home Background & 266 & 0.298 & 0.089 & 0.086 & 5.111 & 8.9 \\
\hline
\end{tabular}

Table 1 shows the correlation coefficient as 0.298 , adjusted $\mathrm{R}^{2}$ value as 0.089 . This shows that $8.9 \%$ of variance in the occurrence of truancy among secondary school adolescents is due to the impact of home background.

Research Question Two: is there any relationship between peer pressure and truancy among adolescent students in Delta State?

Table-2. Relationship between Peer pressure and truancy among adolescent students.

\begin{tabular}{l|l|l|l|l|l|l}
\hline Variable & $\mathbf{N}$ & $\mathbf{R}$ & $\mathbf{R}^{2}$ & $\mathbf{A d j .} \mathbf{R}^{2}$ & $\mathbf{S E E}$ & $\mathbf{R}^{2 \%}$ \\
\hline Peer Pressure & 266 & 0.311 & 0.097 & 0.094 & 5.088 & 9.7 \\
\hline
\end{tabular}

Table 2 shows the correlation coefficient as 0.311 , adjusted $\mathrm{R}^{2}$ value as 0.097 . This shows that $9.7 \%$ of variance in the occurrence of truancy among secondary school adolescents is due to the impact of peer group pressure.

Research Question Three: What is the relationship between Gender and truancy among adolescent students in Delta State?

Table-3. Relationship between Gender and Truancy among adolescents

\begin{tabular}{l|l|l|l|l|l|l}
\hline Variable & $\mathbf{N}$ & $\mathbf{R}$ & $\mathbf{R}^{2}$ & Adj. $^{2}$ & SEE & $\mathbf{R}^{\mathbf{2}} \%$ \\
\hline Gender & 266 & 0.106 & 0.011 & 0.008 & 5.325 & 1 \\
\hline
\end{tabular}

Table 3 shows that the coefficient of relationship between gender and truancy is 0.106 and the $\mathrm{R}^{2}$ is 0.011 and an adjusted $\mathrm{R}^{2}$ value of 0.008 . This means that gender contributed only to $1 \%$ of the variances in the occurrence of truancy amongst secondary school students which is very low.

\subsection{Test of Hypotheses}

Hypothesis One: There is no significant relationship between home background and truancy among secondary school adolescent students.

Table-4. Test of Significant Relationship between home background and truancy among secondary school adolescent students.

\begin{tabular}{l|l|l|l|l|l|l}
\hline Variable & $\begin{array}{l}\text { Summary of } \\
\text { Squares }\end{array}$ & Df & $\begin{array}{l}\text { Mean } \\
\text { Square }\end{array}$ & F. & p-value & Remark \\
\hline Regression & 674.371 & 1 & 674.371 & 25.814 & O.000 & $\begin{array}{l}\text { Significant } \\
\text { relationship }\end{array}$ \\
\hline Residual & 6896.746 & 264 & 26.124 & & & \\
\hline Total & 7571.117 & 265 & & & \\
\hline
\end{tabular}

- Predictors: (Constant), Home Background.

- Dependent variable: Truancy.

Table 4 shows that the calculated factor of variance $(\mathrm{F})$ of 25.814 at p-value of 0.000 indicates that there is a significant relationship between home background and truancy among secondary school students. Based on this, the null hypothesis which states that there is no significant relationship between home background and truancy among secondary school students was rejected. The implication of this is that keeping other variables constant, home background has significant relationship with truancy.

Hypothesis Two: There is no significant relationship between Peer group Pressure and truancy among secondary school adolescent students.

Table-5. Test of Significant Relationship between Peer Pressure and Truancy among secondary school adolescent students.

\begin{tabular}{l|l|l|l|l|l|l}
\hline Variable & $\begin{array}{l}\text { Summary } \\
\text { of Squares }\end{array}$ & Df & $\begin{array}{l}\text { Mean } \\
\text { Square }\end{array}$ & F. & p-value & Remark \\
\hline Regression & 734.391 & 1 & 734.391 & 28.358 & 0.000 & Significant \\
Residual & 6836.726 & 264 & 25.897 & & & \\
\hline Total & 7571.117 & 265 & & & & \\
\hline
\end{tabular}

Table 5 shows that the calculated factor of variance $(\mathrm{F})$ of 28.358 at p-value of 0.000 indicates that there is as significant relationship between peer pressure and truancy among secondary school students. Based on this, the null hypothesis which states that there is no significant relationship between peer pressure and truancy among secondary school students was rejected. The implication of this is that keeping other variables constant, peer pressure has significant relationship with truancy. 
Hypothesis Three: There is no significant relationship between gender and truancy among secondary school adolescent students.

Table-6. Test of Significant Relationship between gender and Truancy among secondary school adolescent students

\begin{tabular}{l|l|l|l|l|l|l}
\hline Variable & $\begin{array}{l}\text { Summary } \\
\text { of Squares }\end{array}$ & Df & $\begin{array}{l}\text { Mean } \\
\text { Square }\end{array}$ & F. & p-value & Remark \\
\hline Regression & 85.807 & 1 & 85.807 & 3.026 & 0.083 & No \\
\hline Residual & 7485.310 & 264 & 28.353 & & & Significant \\
\hline Total & 7571.117 & 265 & & & & \\
\hline \\
\hline
\end{tabular}

Table 6 shows that the calculated factor of variance $(\mathrm{F})$ of 3.026 at p-value of 0.083 indicates that there is no significant relationship between gender and truancy among secondary school students. Based on this, the null hypothesis which states that there is no significant relationship between gender and truancy among secondary school students was accepted. The implication of this is that keeping other variables constant, gender has no significant relationship with truancy.

\section{Discussion of Findings}

The objective of this study was to investigate the relationship between home background, peer group pressure and truancy among adolescent students in Delta State. Although findings from this study revealed that home background and peer group pressure had significant relationship with the occurrence of truancy amongst adolescents. In all of these, it was discovered that they all accounted for $8.9 \%$ and $9.7 \%$ of the occurrence of truancy among secondary school students respectively. These observations are in line with the submissions of Okwakpam and Okwakpam (2012) who noted that home background is a very important determinant factor for the occurrence of truancy among adolescents. According to them, the home is the first place of socialization and the parents must take absolute control and proper monitoring of their wards. The findings in this study is also in favour of the study of Siziya, Muula, and Rudatsikira (2007) who reported that most parents rarely checked homework, neither understood the problems and worries of students nor supervise the students of which in the absence of all these, truancy is bound to occur.

Relative to the influence of peer group pressure, it has been widely submitted by other studies that peer group pressure plays a vital role in the lives of adolescents and that adolescents have a tendency to associate with members of their age group. Findings of this study have been able to corroborate this submission by the significant relationship existing between peer group pressure and truancy. The significant contributions of these variables to the occurrence of truancy among secondary school students is in line with the submissions of Adesoji (2010) who noted that peer group pressure among adolescents is related to their social adjustment.

The findings in this study found no significant relationship between gender and the occurrence of truancy among adolescent students, however this finding disagrees with the finding of Joseph (2008) who observed that there were significant differences between males and females in regards to the various risk factors or characteristics of truant children, but there were no significant difference between males and females in the type of problem area that is affecting their truancy. Also, Dembo, Wareham, Krupa, and Winters (2015) observed that there were gender differences in baseline covariates of sexual risk behaviours, with male truants in higher risk behaviours than their female counterparts. Also showing the significance of gender on the occurrence of truancy as against this study was the findings of Finlay (2005) who observed that gender differences that existed amongst truant youths were outlined in terms of discipline, attendance, achievement, and behaviour. On the overall, both their findings indicated that girls were more likely to be truant because of family obligations whereas boys were more likely to become truant when they had few friends or connections to school.

\section{Conclusion}

This study concluded that home background and peer pressure contributed significantly to truancy amongst secondary school students while gender had no significant relationship

\section{Recommendations}

Based on the following submissions, the following recommendations were made;

- Parents should learn to be close to their wards and as well take note of the friends that they associate with as this will help reduce the level of peer influence on the development of truant behaviours.

- At every level of development, parents, teachers, and counsellors should be available to help them adjust with the attending difficulties associated with the specific developmental stage.

- $\quad$ Teachers and parents should help in proper monitoring of student activities so as to help sustain the low level of truancy amongst students as observed in this study. 
- $\quad$ Every parent and elder siblings should see themselves as role models that engender good behaviours to their children as the kind and form of mentoring giving by parents contributes in the sharpening of adolescent attitudes and behaviours.

\section{References}

Adesoji, A. O. (2010). Peer group pressure as a determinant of adolescent social adjustment in Nigerian schools Asian pacific. Journal of Educators and Education, 25, 189-202.

Azizi. (2009). Impact of peers on secondary school adolescents. Ibadan: Herman Educational Publisher.

Bucci, A. M. (2002). School attendance and attachment: Whitehouse school focus youth service (pp. 10): Box Hill.

Capps, W. R. (2003). The new face of truancy. School Administration, 60, 34.

Dembo, R., Wareham, J., Krupa, J., \& Winters, K. C. (2015). Sexual risk behavior among male and female truant youths: Exploratory, multi-group latent class analysis. Journal of Alcoholism and Drug Dependence, 3(6), $226-236$.

Ezewu, E. E. (1983). Sociology of education. London: Longman.

Finlay, K. A. (2005). Gender differences among truant youth: A Publication of Colorado Foundation for Families and Children, National Center for School Engagement United States of America.

Gonzales, R., Richards, K., \& Seeley, K. (2002). Touth out of school: Linking absences to delinquency. Denver, CO: Colorado Foundation for Families and Children.

Joseph, A. (2008). A study of elementary school children at risk for truancy: Exploring gender differences, services offered, and other factors related to truancy. Unpublished Master Degree Theses Graduate Faculty, Louisiana State University and Agricultural and Mechanical College.

Michael, K. J. (2005). Manual to combact truancy. New York: McGraw Hill Book Company Inc.

Obe, E. O. (1998). School indiscipline and remedies. Lagos: Premier Press and Publisher Ltd.

Odueze, B. C. (2001). The causes of truancy among primary school pupils in Mbaano local government area. Unpublished Thesis, Imo State University.

Okwakpam, I. N., \& Okwakpam, I. O. (2012). Causes and levels of truancy among secondary school students: A case study of rivers state, Nigeria. Problems of Education in the 21 st Century, 45, 51-62.

Osarenren, N. A. C. (1999). Absenteeism and truancy in education. Obe (Ed) school and remedies. Lagos: Premier Press and Publishers.

Reid, K. (2000). Tackling truancy in schools: A practical guide for primary and secondary schools. London: Routledge.

Siziya, S., Muula, S., \& Rudatsikira, E. (2007). Prevalence and correlates of truancy among adolescents in Swaziland: Findings from the global school-based health survey. Child and Adolescent Psychiatry and Mental Health, 1(15), 1-8.

Stoll, A. C. (2002). Deliquency among secondary school students. New York: McGraw Hill Book Company Inc. 